\title{
LUT
}

University

The role of performance measurement in developing industrial services

Pekkola Sanna, Saunila Minna, Ukko Juhani, Rantala Tero

This is a Post-print version of a publication

published by Emerald Group Publishing Limited

in Journal of Quality in Maintenance Engineering

DOI: $10.1108 / J Q M E-01-2015-0004$

Copyright of the original publication: @ Emerald Group Publishing Limited 2016

Please cite the publication as follows:

Pekkola S., Saunila M., Ukko J., Rantala T. (2016). The role of performance measurement in developing industrial services. Journal of Quality in Maintenance Engineering, vol. 22, issue 3. pp. 264-276. DOI: 10.1108/JQME-01-2015-0004

This is a parallel published version of an original publication. This version can differ from the original published article. 


\section{THE ROLE OF PERFORMANCE MEASUREMENT IN DEVELOPING INDUSTRIAL SERVICES}

\section{Structured abstract}

Purpose - This study examines inter-organisational cooperation in delivering maintenance services, focusing on the level of maturity of this cooperation and the current role of performance measurement in evaluating its effectiveness. It also determines how performance measurement should be developed to support the needs of networked maintenance.

Design/methodology/approach - The empirical evidence is based on two cases of networks operating in the field of industrial maintenance. The first network operates in the energy industry, while the second operates in the mining industry. Both networks consist of machine supplier companies, performance partner companies and system supplier companies. A total of seven companies participated in workshops and interviews in 2013-2014.

Findings - As a result of the study, suggestions for improving the performance measurement of service value in maintenance are presented and a framework is offered that meets the needs of the customer, service provider and equipment provider. The significant innovation of the research is its combination of network, service and value perspectives in performance measurement by presenting a framework for measuring created value of cooperation.

Originality/value - The literature calls for new measurement models and frameworks that support the new management challenges. This research creates a framework for practical applications. The framework helps to identify possible development needs and increases our understanding of what is required when cooperation in a maintenance network deepens, moving from machine partner towards value partner.

Keywords - Performance measurement, value, maintenance, service

Article classification - Research paper

\section{Introduction}

Today, small and medium-sized enterprises are competing in globalised and turbulent markets. To survive in such a competitive environment, companies have to collaborate with each other with the objective of meeting customers' needs more effectively and efficiently (Bititci et al., 2004; 2012; Benedettini et al., 2015). Companies operating in networks require information regarding the functionality and value of the network (Kaplan et al., 2010; Bititci et al., 2012). Traditionally, operations management literature has addressed the subject of value when considering manufacturers' strategies for adding value for their customers (Lightfoot et al., 2013). When operating in networks, each organisation's role and value input have to be taken into account. In their investigation of how value is created in networks, Ulaga and Chacour (2001) concluded that it is created not only by delivering products and services but also through relationships. Understanding this requires extensive shared information throughout the network. 
The literature reveals that a lack of network-level performance management may have many consequences that can affect the performance of individual companies and lead to a suboptimisation of or even a decrease in the performance of the whole business network (see e.g. Kulmala and Lönnqvist, 2006; Busi and Bititci, 2006; Kaplan et al., 2010; Lönnqvist and Laihonen, 2012). In order to be successful, it is important for the network to continuously evaluate and enhance the performance of the individual partners as well as the entire network (Kaplan et al., 2010).

This research study focuses on industrial services, especially maintenance services in Finland. The competition in international markets has led to a situation where industrial maintenance services are increasingly outsourced (Muchiri et al., 2011, Neely, 2009). As a result, competition that once existed between companies has shifted to competition between networks in which the role of maintenance service and equipment suppliers has become more and more integrated into the customer's value-creation process. Thus, all partners have a common interest in developing industrial services. These interests relate, for example, to achieving profitable growth, building synergies and offering an optimal value proposition (Bititci et al., 2004). The management challenge lies in how to manage the transition from inner-organisational cooperation to interorganisational cooperation. Many companies refer to 'developing a new mindset' in the organisation as the main challenge to establishing new 'roles'. Thus, the study aims to examine the following research questions:

- What kinds of cooperation exist in maintenance services?

- What is the current role of performance measurement in managing networked maintenance services?

- How should performance measurement be developed so that it supports the needs of networked maintenance?

The overall goal is to understand networking in industrial services, especially the maintenance service environment in Finland. Empirical data has been gathered from seven Finnish customers, equipment suppliers and maintenance service companies by using interviews and workshops. The paper consists of four sections. First, a literature review summarises previous research on performance management, measurement systems and value creation in network environments. It also examines the classification of industrial services in Finland and creates the research framework for the study. The next section explains the methodology used in the data collection, after which the findings are outlined. Finally, the paper offers conclusions and recommendations for practice and suggestions for further research. The significant novelty of the research is based on combining network, service and value perspectives in maintenance performance measurement and management. In addition, the paper highlights the role of measuring intangible value when the cooperation stage gets more mature.

\section{Theoretical background}

\subsection{Value perspective in services networks}

The basic nature of value can be discussed by examining the following two general meanings of value: 'value-in-use' and 'value-in-exchange' (Vargo et al., 2008). The traditional view of value creation is related to a goods-dominant logic, which is based on value-in-exchange where value 
is created by organisations, usually through the exchange of products and goods (e.g. Vargo and Lusch, 2004). In general, value-in-exchange can be regarded as a short-term trade-off between organisations' sacrifices and benefits. The alternative view of value creation, 'value-in-use', is related to a service-dominant logic where the roles of producers and customers are not distinct, meaning that value is co-created (Vargo and Lusch, 2008; Vargo et al., 2008).

Service-dominant logic offers an alternative point of view for evaluating an organisation's strategic positioning, considering its operations from a network-oriented perspective that facilitates the exploration of new value-creation mechanisms in an industrial context (Hallikas et al., 2014). Moving the locus of value creation from exchange to use means transforming the understanding of value from one based on units of an organisation's output to one based on processes that integrate resources. Manufacturing-centred ideology faces challenges in the form of business models driven by the requirements of business-to-business (B-to-B) customers for more complex product-service systems (Hallikas et al., 2014). According to definitions in the literature, service systems are assumed to comprise interactions between the manufacturer, supplier and customer as well as the exchange of certain intangible value inputs and functions (Goldstein et al., 2002). A service system can be seen as an arrangement of resources (including people, technology and information) connected to other systems by value propositions (Spohrer et al., 2007). Organisations' roles in value creation in service systems (including the proposition and provision of service) are intermediary to the value co-creation process. A service system's function is to make use of its own resources and the resources of others to improve its own circumstance and that of others (Vargo et al., 2008).

As maintenance operations and services have been moving from businesses focused on goods and products to functions associated with partnerships and service provision, the role of value creation and value networks has been increasingly emphasised in the literature (Lusch et al., 2010). A value network can be seen as formally or informally connected operators which interact together in order to co-produce services and co-create value by combining their resources and knowledge. A value network has structural integrity because each member organisation has competences (used to offer and provide services to others) and information that can be shared through the network (Lusch et al., 2010). The value delivered through the service and value networks is usually formed by the needs of the customer organisation or the final user of the services. In this process, the value of a service can be considered to consist of different value inputs (e.g. safety, flexibility, reliability and price). Furthermore, the perceived total value for the customer and service provider can be considered as the sum and right combination of these value inputs (e.g. Ojanen et al., 2012; Ali-Marttila et al., 2013). However, for maintenance-based service networks, conceptualisation of the value-creation process should pay more attention to the value outcome created by the whole network instead of focusing solely on the value outputs that individual network partners receive. In this context, performance measurement and management play a significant role.

\subsection{Performance measurement and management in networks}

If companies aim to create and sustain a competitive advantage through networks, the structures of the network need to be understood and managed (e.g. Neely, 2009; Pekkola, 2013). Otherwise, the objectives will not be achieved and the network will fail (Verdecho et al., 2009). Traditionally, 
networks are usually organised and managed as single organisations; however, this is not an appropriate approach in the network context (Kaplan et al., 2010). In order to develop and manage a successful business network, continuous performance measurement in both the single network partner and the entire network is needed to organise the collaboration successfully (Pekkola, 2013; Pekkola et al., 2013). In addition, in order to understand how a performance measurement system in a network has developed and is used, it is necessary to capture its context, process and content (Cuthbertson and Piotrowicz, 2009). It is important to define the conditions in which the measurement takes place. Performance measurement can be seen as a tool that produces the necessary network-level information, promotes network management effectively and enhances the success of collaborative processes by, for example, reducing organisation-level sub-optimisation (Verdecho et al., 2009; Bititci et al., 2012). Comprehensive network-level performance measurement systems can provide essential information for the entire network, manage the processes of the network and guide the network partners towards common goals (Kulmala and Lönnqvist, 2006; Kaplan et al., 2010; Bititci et al., 2012).

However, management and measurement of the network is very complicated because the network consists of individual firms that have only transactional ties to the network. The literature (Kaplan et al., 2010) presents several critical success factors and characteristics that play a key role in the success of a network and which are related to the analysis and management of performance measurement:

- Commitment: The willingness of the trading partners to exert effort on behalf of the relationship.

- Trust: The network partners should trust each other.

- Coordination: This is related to boundary definitions and reflects the set of tasks each network member expects the others to perform.

- Communication quality: This should be timeless, accurate and complete.

- Participation: This refers to the extent to which the partners engage jointly in planning and goal setting.

- Joint problem: The firms in a strategic partnership are motivated to engage in a joint problem.

Despite the challenges mentioned above, a crucial component of a service system is the customer and the value s/he perceives. Indeed, the overall aim of the service system is to provide added value to the customer (Vargo and Lusch, 2008; Spohrer et al., 2007).

The existing models and frameworks in the literature concentrate on condition monitoring and measuring the performance of individual network members. Overall, there are various models for monitoring the different parts of the maintenance process (Muchiri et al., 2011). However, the network provides value that the current models do not take into account. The value provided by the network can be both financial (direct or indirect) and non-financial (Liyanage and Kumar, 2003). Intangible non-financial values can be as important as tangible values and thus there is a need to understand the intangible values which create the perception of benefit for the customer of the network (Toossi et al., 2013). Therefore, in order to deliver services, organisations should adopt performance measures that reflect outcomes aligned with customers' expectations. These 
can then be combined into measures for individual organisations and complemented by a set of more emotional measures that demonstrate value to the customer (Baines and Lightfoot, 2014).

\subsection{Maintenance cooperation}

Organisations in many industries have outsourced their non-core activities to their suppliers in order to focus on their strategy while acquiring required capabilities with increased cost efficiency and economic value (e.g. Bititci et al., 2004). The aim of service purchasing is to attain value from outsourced and integrated services. Services are considered even more important than the purchase good on account of their better profit-increasing potential (Hallikas et al., 2014). In this situation, companies move closer to their customers, which brings about the need for new product concepts and service models. In their examination of Finnish industrial services, Kalliokoski et al. (2003) identified and defined five supplier positions or "roles" relative to the customer:

- Machine supplier: The focus of the business relationship is on delivering a piece of machinery or equipment that fits the customer's technical specification.

- System supplier: The focus of business is on delivery of a system, for example a production line, which is usually designed for the specific customer's process and comprises a wider scope of supply than just one piece of equipment. The roles of both machine supplier and system supplier focus on the customer's investment decision, with limited involvement in the remaining life cycle of the delivered unit.

- Maintenance partner: The focus of business expands in this role to include continued supplier involvement during the ongoing life cycle of the product. This role adds contractual aftermarket elements such as spares and consumables agreements to the supplier-customer relationship.

- Performance partner: In this role the supplier is closely involved in operating the customer's technical process by taking part responsibility for the performance of the system, for example through availability warranties. This role requires the supplier to maintain at least a minimum continuous on-site presence. The focus of the customer relationship is on securing the effective operation of the unit or production line.

- Value partner: The supplier here is directly involved in the customer's business, for example through operate and maintain agreements where the customer pays a predetermined price for the actual output of the system. Both parties focus on profitable daily operations, and the supplier is responsible for the day to-day operation of the plant or line.

Building on this categorisation, the aim of this study is to examine the kinds of 'role' that service producers have and how the value of this cooperation can be measured (figure 1). 


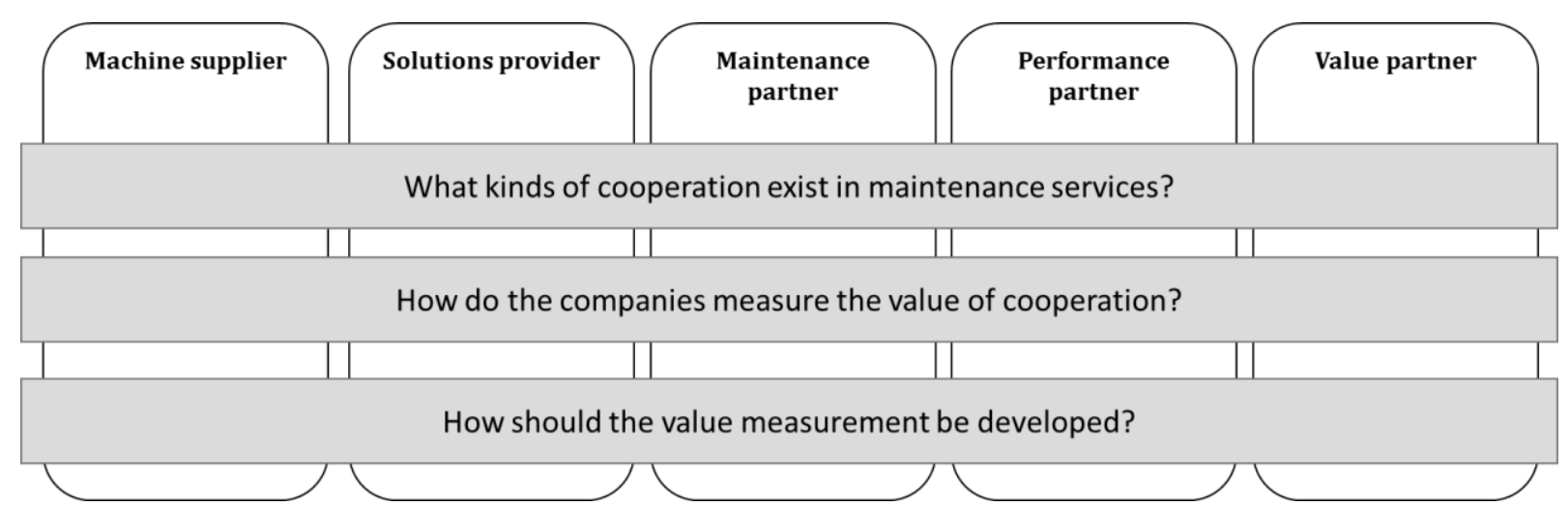

Figure 1. Research questions

\section{Research approach}

The results of this study are based on two case studies. Because of the exploratory nature of the research, the case study was deemed appropriate as an approach because of the importance of the phenomenon in practice as well as the lack of existing theory. Two networks made up of seven organisations which operate in the mining and energy industries were used as case studies. Both of the networks included companies with the following three different roles: a customer company, a maintenance service provider company and an equipment provider company. These networks were chosen as cases because they were interested in developing performance measures for monitoring the value created in the network.

The empirical data was collected from a total of six workshops (three workshops per network) in 2014 (see table 1). The aim of the first workshop was to identify the context where the network operates and the current state of the cooperation. Consideration was given also to how mature the network is (looking at its vision, strategy and targets). The second workshop concentrated on the measures that the companies used to identify the value of their services/equipment (in the case of the equipment provider and maintenance service provider) or the value of the purchased services (in the case of the customer company). In addition, development needs for value measurement were identified. The third workshop focused on the development of a framework relating to how the value of cooperation can be measured in the cooperative roles in the network (cf. Kalliokoski et al., 2003). After developing this pre-understanding, the different value inputs and their importance in each network partner's role were clarified and principles of value measurement were identified.

In order to validate the findings, case triangulation was used. First, the research process was carried out in the case of the energy network, after which the results were validated using the mining network. Similar research processes were used for both networks to ensure scientific transparency and repeatability. The data included written assignments completed by the representatives of the participating companies as well as documented focus group meetings. After the workshops, nine people in each network were interviewed using semi-structured interviews. The interviewed participants were in part also workshop participants and the questions related to themes addressed in the workshops. The interviews were recorded and transcripts were made. 
Table 1. Workshop and interview study participants

\begin{tabular}{|l|l|l|}
\hline ENERGY NETWORK & Workshop participants & Interviewed participants \\
\hline Customer company & Head of Production 1 & Head of Production 2 \\
\hline Maintenance service provider & $\begin{array}{l}\text { Vice President-Sales and } \\
\text { Marketing; Director-Service } \\
\text { Offerings and Development }\end{array}$ & $\begin{array}{l}\text { Executive Vice President- } \\
\text { Business Development }\end{array}$ \\
\hline Equipment provider 1 & Maintenance Manager & $\begin{array}{l}\text { Maintenance Manager; Service } \\
\text { Manager }\end{array}$ \\
\hline Equipment provider 2 & Customer Service Engineer & N/A \\
\hline MINING NETWORK & Workshop participants & Interviewed participants \\
\hline Customer company & Department Manager & $\begin{array}{l}\text { Department Manager, Director of } \\
\text { Production }\end{array}$ \\
\hline Maintenance service provider & CEO & CEO \\
\hline Equipment provider & Specialist & Specialist \\
\hline
\end{tabular}

Four researchers cooperated with respect to the content analysis, after which the common view was discussed. Although the study belongs to the performance measurement and management research stream, maintenance and service operations management research was also used to integrate existing theory with new contexts. Data triangulation was used by collecting more than one source of data. The written assignments focused on the success factors of the network as well as its current measures, including their weaknesses and strengths. The topics of the focus group meetings were selected based on the written assignments and the analysis of the previous meeting. Thus, although the topics and issues were decided beforehand, the discussions were informal and facilitated through leading questions and the researchers' comments.

To summarise this section, the validity and reliability was achieved by following an exact procedure in performing the qualitative analysis, from data collection to interpretation. In addition to case triangulation, researcher triangulation, theory triangulation and data triangulation were also used to validate the findings. The transparency of the research process, as well as utilising multiple researchers in the analysis, has increased the rigour of the results.

\section{Findings}

4.1 Cooperation in maintenance service networks and the current role of performance measurement The increase in maintenance outsourcing indicates that companies believe that they can achieve added value from a new kind of network and cooperation models. In addition, previous studies have demonstrated that companies can improve their profitability and overall competitiveness through incorporating new services systematically into their business. The starting point of this study was to understand the state of cooperation and the role of performance measurement in maintenance services by using the framework of Kalliokoski et al., 2003.

The findings of the empirical evidence (figure 2) demonstrate that maintenance service partners (especially machine suppliers and solutions providers) cooperate on a purely transactional basis with others, cooperating closely only when they are planning annual stoppages. In the case of 
these companies that provide equipment and product maintenance, the maintenance was often corrective maintenance. However, in the case of the companies that produce only services, there was a more mature level of cooperation with the customer company, including joint targets. The participants in both cases were not able to name a case of a value network partnership where the collaboration is structured and managed systemically. Based on the empirical findings, the companies are not yet prepared and mature enough for network-level performance measurement and matured collaboration is favoured instead (cf. Pekkola et al., 2013).

The results of the interviews reveal that a more matured cooperation is not possible because the current business models of the customer companies does not support it. The customer companies buy in services for only some parts of their maintenance processes. Any wider outsourcing requires a more matured knowledge of what the company actually outsources and the benefits and risks. The interviewed customer company representatives revealed that they do not have this kind of knowledge and so willingness to move to a more networked business model is lacking. They also pointed out that this would need detailed planning process with respect to what is outsourced, who it affects, how it should be operationalised, and which of the current structures and processes would need to be removed.

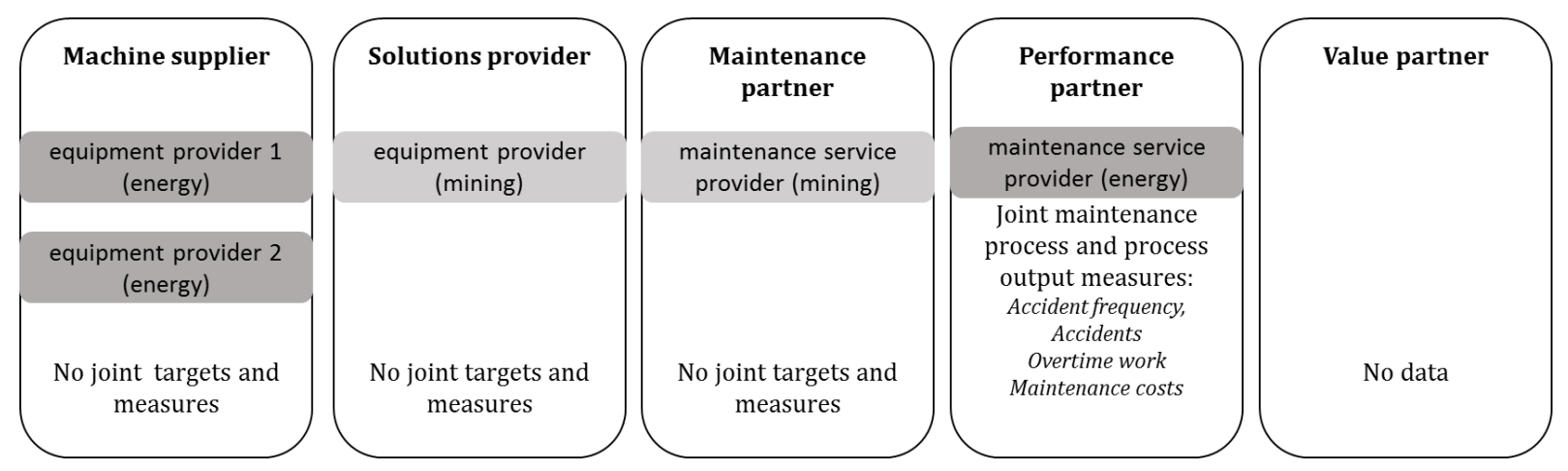

Figure 2. The role of companies in the case studies and the current state of value measurement.

The empirical evidence also shows that the maintenance companies do not have joint measures for measuring the success or value of the cooperation. The machine and service providers described the situation as follows:

We just deliver the machine or service that we are promised. Of course we ensure that the customer is satisfied and the machine works as promised. (Service provider.)

In this role, we do not need joint measures. But if networking becomes more mature, then we need measures to support collaboration and evaluate its value. (Machine and service supplier.)

The results reveal that at the performance partner level, the service provider does have measures that are imposed by the customer in the maintenance contract. The target and control levels are jointly discussed and elaborated between the service provider and the customer. If the performance partner is not able to fulfil the promises, identified sanctions have to be paid to the 
customer company. These measures focus on the efficiency and effectiveness of the maintenance process as well as the outputs of the process.

When we do the agreement with the performance partner, we discuss and agree the measures (maintenance costs, loss of production), sanctions and meeting and reporting practices. (Customer company.)

However, the maintenance partners emphasise that their target is to be a value partner for the customers despite the role they currently play. The participants highlight that there is a need for tools that measure the value of a machine or maintenance service to the customers. Based on this need, a framework for measuring the value of maintenance cooperation was elaborated with the assistance of the case study companies.

\subsection{Framework for measuring the value of maintenance cooperation}

In maintenance services, as well as service production in general, the main challenge is to measure how customer needs are fulfilled through experience and valuation (cf. Goldstein et al., 2002). Ulwick and Bettencourt (2008) reveal that difficulties in measuring customer value tend to arise due to the existence of non-functional value components. Customer perceptions of such value are difficult to address before the realisation of the service delivery, the value of which is strongly related to the problem-solving process in which the customer is engaged (Ulwick and Bettencourt, 2008).

This study presents a framework for measuring the value of cooperation and networking. The framework is based on the five maintenance cooperation roles defined by Kalliokoski et al. (2003), as well as the value creation, performance measurement and networking literature and the participants' perceptions concerning value expectations and performance measurement. The participants' suggestions form the basis of the framework which articulates the mechanisms and principles for measuring the value of maintenance cooperation (table 2).

Table 2. The maturity framework for measuring the value of maintenance cooperation

\begin{tabular}{|c|c|c|c|}
\hline $\begin{array}{l}\text { Partner role } \\
\text { stage }\end{array}$ & & $\begin{array}{l}\text { Measurement target } \\
\text { for example }\end{array}$ & $\begin{array}{l}\text { Measures } \\
\text { for example }\end{array}$ \\
\hline $\begin{array}{l}\text { Machine } \\
\text { supplier }\end{array}$ & $\begin{array}{l}\text { A one-time } \\
\text { supplier (piece of } \\
\text { machinery) }\end{array}$ & - Customer expectations & $\begin{array}{l}\text {-delivery time } \\
\text { - usability } \\
\text { - discharge level } \\
\text { - customer satisfaction }\end{array}$ \\
\hline $\begin{array}{l}\text { Solutions } \\
\text { provider }\end{array}$ & $\begin{array}{l}\text { A one-time } \\
\text { supplier (designed } \\
\text { for the specific } \\
\text { customer's } \\
\text { process) }\end{array}$ & - Customer expectations & $\begin{array}{l}\text {-delivery time } \\
\text { - usability } \\
\text { - discharge level } \\
\text { - customer satisfaction }\end{array}$ \\
\hline $\begin{array}{l}\text { Maintenance } \\
\text { partner }\end{array}$ & $\begin{array}{l}\text { A continued } \\
\text { supplier } \\
\text { involvement }\end{array}$ & $\begin{array}{l}\text { - Jointly decided targets for } \\
\text { cooperation: what the customer } \\
\text { company expects and what the } \\
\text { supplier promises }\end{array}$ & $\begin{array}{l}\text { - service delivery time } \\
\text { - usability } \\
\text { - quality of communication }\end{array}$ \\
\hline
\end{tabular}




\begin{tabular}{|l|l|l|l|}
\hline $\begin{array}{l}\text { Performance } \\
\text { partner }\end{array}$ & $\begin{array}{l}\text { Closely involved in } \\
\text { the customer's } \\
\text { technical process }\end{array}$ & $\begin{array}{l}\text { - Jointly decided targets for } \\
\text { cooperation: what the customer } \\
\text { company expects and what the } \\
\text { supplier promises } \\
\text { - value of partners (e.g. savings) } \\
\text { - value of end customer }\end{array}$ & $\begin{array}{l}\text { - end customer satisfaction } \\
\text { - cost/saving benefits for the } \\
\text { participants }\end{array}$ \\
\hline $\begin{array}{l}\text { Value } \\
\text { partner }\end{array}$ & $\begin{array}{l}\text { Directly involved } \\
\text { in the customer's } \\
\text { business }\end{array}$ & $\begin{array}{l}\text { - Value of collaboration (outcomes) } \\
\text { - financial value }\end{array}$ & $\begin{array}{l}\text { - end customer satisfaction } \\
\text { - sustainability of collaboration } \\
\text { - network relationships }\end{array}$ \\
\hline
\end{tabular}

Machine supplier and solutions provider cooperation: The empirical data emphasised that the machine and solution suppliers have to understand the customer's expectations. These expectations are often related to the promises the supplier made to the customer. Neely et al. (2011) state that service delivery can be effectively hidden from the customer and that the business thus has to work hard to educate the customer about the value of the service delivered. The role of the supplier, then, is to understand and measure the customers' value-creation processes embedded in the customers' practices and contexts. Therefore, the machine/solutions provider should measure these expectations (e.g. delivery time, usability, discharge level and customer satisfaction) to ensure that value is created through the cooperation. This can involve a simple customer survey, where the supplier asks for the customer's opinion after the service/equipment production and analyses the results case-by-case in order to develop services and processes based on that information.

Maintenance partner cooperation: Maintenance partner cooperation involves maintenance of a machine or product line during the whole life cycle. Participants from the two case study companies highlighted that the partners should create joint targets (what the customer company expects and what the supplier promises) and measures for this cooperation and thus ensure that cooperation creates the desired value. In this way the maintenance partner can indicate that the service is valuable to the customer company. This discussion is also connected to the following question: Is it more valuable for the customer to purchase corrective maintenance where maintenance is carried out after fault recognition or predetermined maintenance where the maintenance is carried out in accordance with established intervals of time?

Performance partner cooperation: This cooperation is more structured and there are already measured joint goals for the efficiency and effectiveness of the maintenance processes. In addition to these measures, the partners should be able to evaluate and measure the value created by this cooperation for both participants. For example, the measurement could focus on issues such as end customer satisfaction and cost/saving benefits for the participants. A comprehensive measurement requires that all measures are linked together so that causal linkages between firmlevel measures and network-level measures can be formed. The network value measures should be common to the entire network (cf. Pekkola, 2013). The empirical evidence indicates that the current state of measurement is not focused on the value of the cooperation. Instead, it only focuses on the current production process measures. In this kind of cooperation, the value measurement should be systemic (Laihonen et al., 2014) rather than organisational-centric. 
Value partner networking: Value partner networking can be defined as a more advanced and demanding form of maintenance collaboration. It involves a joint process where the entities share information, resources and responsibilities to plan, implement and evaluate activities in order to achieve a common goal (Camarinha-Matos et al., 2009). In this form of collaboration, the value of collaboration should be measured more systematically in order to ensure mutually beneficial collaboration. Based on the workshops and network literature, the following five value dimensions were defined as being important for the measurement of the network's value: financial results, end customer experience, sustainability and relationships. The operationalisation of these measures is not seen as very likely because of the lack of business models in industrial services.

In summary, it can be stated that combining maturity perspective in maintenance value and cooperation measurement assists in recognising the state of cooperation. After that it can be improved one step at a time. This assists in finding out if a company is mature for certain types of cooperation solutions and help moving to the next step of value creation.

\section{Conclusions}

This study increases our understanding of the measurement of value in maintenance services. The competition in international markets has led to a situation where industrial maintenance services are outsourced; thus, there is a need for a theory that elucidates how the actual value of such cooperation can be demonstrated to the partners and end customers. Despite the increasing amount of literature on performance measurement in networks, there remains very little theory that reflects the complexity and dynamism of when value is delivered to customers through maintenance cooperation. This study extends the literature on performance measurement of value from individual organisations to a network level.

The results of the study show that networking is at an early stage in maintenance services. It is mainly based on transactional costs without value network or win-win thinking. Even though the maintenance service company's role is similar to that of a performance partner, discussion of the value of such cooperation is still lacking. However, the results reveal that the case study companies identify a need to measure and evaluate the value of the cooperation and promote such discussions of value with the customer company. The study presents some principles for measuring the value of different forms of cooperation. For equipment suppliers and solutions providers, the role of value measurement could focus on the satisfaction of the customer company. However, in cases of more mature forms of cooperation, the companies should have joint targets for the cooperation and measures that evaluate how the value has been created. As its main contribution, the study presents a framework and suggestions for how to measure value in maintenance services. In terms of its practical contribution, it presents a framework that can be used as a tool when developing measurements for monitoring and analysing maintenance cooperation. It also increases understanding of how to manage the transition between these evolving steps and helps to develop a 'new mindset' in the organisation by establishing new 'roles' in cooperation. As another practical implication, the results of the research may help maintenance professionals begin to understand that all partner role stages create value. By recognising the current state of cooperation, its improvement and deepening is possible. 
The results of the study are based on empirical evidence from seven organisation that have different roles in maintenance cooperation. The results are not generalizable more widely, but they give a tentative understanding of networking in maintenance services, its measurement and its development needs. Future research should focus on what kind of measures are practical for assessing the value of cooperation and how these measures can be designed, implemented and used in maintenance cooperation.

\section{References}

Ali-Marttila, M., Tynninen, L., Marttonen, S., Kärri, T. (2013), "Solving the value puzzle of the customer and service provider in industrial maintenance services", Proceedings of the Maintenance Performance Measurement and Management Conference 12th-13th September 2013, Lappeenranta, Finland.

Baines, T. and Lightfoot, H.W. (2014), "Servitization of the manufacturing firm: Exploring the operations, practices and technologies that deliver advanced services", International Journal of Operations and Production Management, Vol. 34 No. 1, pp. 2-35.

Busi, M. and Bititci, U.S. (2006), "Collaborative performance management: Present gaps and future research", International Journal of Productivity and Performance Management, Vol. 55 No. 1, pp. 7-25.

Bititci, U.S., Garengo, P., Dörfler, V. and Nudurupati, S. (2012), "Performance measurement: Challenges for tomorrow", International Journal of Management Reviews, Vol. 14 No. 3, pp. 305-327.

Bititci, U.S., Martinez, M., Albores, P. and Parung, J. (2004), “Creating and managing value in collaborative networks", International Journal of Physical Distribution and Logistics Management, Vol. 34 No. 3, pp. 251-268.

Camarinha-Matos, L.M., Afsarmanesh, H., Galeano, N. and Molina, A. (2009), "Collaborative networked organizations: Concepts and practice in manufacturing enterprises", Computers and Industrial Engineering, Vol. 57 No. 1, pp. 46-60.

Cuthbertson, R. and Piotrowicz, W. (2011), "Performance measurement systems in supply chains: A framework for contextual analysis”, Vol. 60 No. 6, pp. 583-602.

Goldstein, S.M., Johnston, R., Duffy, J. and Rao, J. (2002), "The service concept: The missing link in service design research?" Journal of Operations Management, Vol. 20 No. 2, pp. 121-134.

Hallikas, J., Immonen, M., Pynnönen, M. and Mikkonen, K. (2014), "Service purchasing and value creation: Towards systemic purchases", International Journal of Production Economics, Vol. 147, pp. 53-61.

Kalliokoski, P., Andersson, G., Salminen V. and Hemilä, J. (2003), BestServ: Feasibility Study Final Report, Teknologiateollisuus ry, Helsinki, Finland.

Kaplan, R.S., Norton, D.P. and Rugelsjoen, B. (2010), "Managing alliances with the balanced Scorecard”, Harvard Business Review, Vol. 88 No. 1, pp. 68-75.

Kulmala, H.I. and Lönnqvist, A. (2006), "Performance measurement of networks: Towards a nonfinancial approach", International Journal of Networking and Virtual Organisations, Vol. 3 No. 3, pp. 299-316. 
Lightfoot, H., Baines, T. and Smart, P. (2013), "The servitization of manufacturing: A systematic literature review of interdependent trends", International Journal of Operations and Production Management, Vol. 33 Nos. 11/12, pp. 1408-1434.

Liyanage, J.P. and Kumar, U. (2003), "Towards a value-based view on operations and maintenance performance management", Journal of Quality in Maintenance Engineering, Vol. 9 No. 4, pp. 333-350.

Lusch, R.F., Vargo, S.L and Tanniru, M. (2010), "Service, value networks and learning”, Journal of the Academy of Marketing Science, Vol. 38 No. 1, pp. 19-31.

Lönnqvist, A. and Laihonen, H. (2012), "Welfare service system productivity: The concept and its application", International Journal of Productivity and Performance Management, Vol. 61 No. 2, pp. 128-141.

Muchiri, P., Pintelon, L., Gelders, L. and Martin, H. (2011), "Development of maintenance function performance measurement framework and indicators", International Journal of Production Economics, Vol. 131 No. 1, pp. 295-302.

Neely, A. (2009), "Exploring the Financial Consequences of the Servitization of Manufacturing", Operations Management Research, 2, 1, pp. 103-118.

Neely, A., Benedettini, O. and Visnjic, I. (2011), "The servitization of manufacturing: Further evidence", 18th European operations management association conference, 3-6th July, 2011, Cambridge, UK.

Ojanen, V., Hatinen, L., Kärri, T, Kässi, T. and Tuominen, M. (2012), "Flexible investment planning and collaborative maintenance management", in: van der Lei, T., Herder, P. and Wijnia, Y. (Eds.), Asset Management: The State of the Art in Europe from a Life Cycle Perspective, Springer, Dordrecht, Netherlands, pp. 65-77.

Benedettini, 0., Neely, A. and Swink, M. (2015), "Why do servitized firms fail? A risk-based explanation", International Journal of Operations \& Production Management, Vol. 35 Iss: 6, pp.946 - 979

Parung. J. and Bititci, U.S. (2006), “A conceptual metric for managing collaborative networks", Journal of Modelling in Management, Vol. 1 No. 2, pp. 116-136.

Parung, J. and Bititci, U.S. (2008), "A metric for collaborative networks", Business Process Management Journal, Vol. 14 No. 5, pp. 654-674.

Pekkola, S. (2013), "Managing a network by utilizing performance measurement information", Measuring Business Excellence, Vol. 17 No. 1, pp. 72-79.

Pekkola, S., Niemi, P. and Ukko, J. (2013), "Building understanding of the development of performance management for collaborative networks with a knowledge maturity model", International Journal of Networking and Virtual Organisations, Vol. 12 No. 3, pp. 179-200.

Spohrer, J., Maglio, P., Bailey, J. and Gruhl, D. (2007), “Steps towards a science of service systems”, Computer, Vol. 40 No.1, pp. 71-77.

Toossi, A., Lockett, H.L., Raja, J.Z. and Martinez, V. (2013), "Assessing the value dimensions of outsourced maintenance services", Journal of Quality in Maintenance Engineering, Vol. 19 No. 4, pp. 348-363.

Ulaga, W. and Chacour, S. (2001), "Measuring customer-perceived value in business markets", Industrial Marketing Management, Vol. 30 No. 6, pp. 525-540.

Vargo, S.L. and Lusch, R.F. (2004), "Evolving to a new dominant logic for marketing", Journal of Marketing, Vol. 68 No. 1, pp. 1-17. 
Vargo, S.L. and Lusch, R.F. (2008), "Service-dominant logic: Continuing the evolution", Journal of the Academy of Marketing Science, Vol. 36 No. 1, pp. 1-10.

Vargo, S.L., Maglio, P.P. and Akaka, M.A. (2008), "On value and value creation: A service systems and service logic perspective", European Management Journal, Vol. 26, pp. 145-152.

Verdecho, M.J., Alfaro, J.J. and Rodriguez-Rodriguez, R. (2009), "Foundations for collaborative performance measurement", Production Planning and Control, Vol. 20 No. 3, pp. 193-205. 